\title{
The Rise and Fall, and the Rise (again) of Feminist Research in Music: 'What Goes
}

\section{Around Comes Around'}

Sally Macarthur, Dawn Bennett, Talisha Goh, Sophie Hennekam, Cat Hope

\begin{abstract}
The article reports from a two-phase study that involved an analysis of the extant literature followed by a three-part survey answered by 71 women composers. Through these theoretical and empirical data, the authors explore the relationship between gender, and symbolic and cultural capital in music. Bourdieu's theory of the habitus is employed to understand the gendered experiences of the female composers who participated in the survey. The article suggests that these female composers have different investments in gender but that, overall, they reinforce the male habitus given that the female habitus occupies a subordinate position in relation to that of the male. The findings of the study also suggest a connection between contemporary feminism and the attitudes towards gender held by the participants. The article concludes that female composers classify themselves, and others, according to gendered norms and that these perpetuate the social order in music in which the male norm dominates.
\end{abstract}

\section{Introduction}

In the world of contemporary music composition, gender remains a live feminist issue given that classical music is ‘a male haven’ (Maddocks 2011) from which women composers are largely excluded. In this article, we will discuss the marginalisation of women composers, acknowledging that the issues raised by their plight in this present decade of the twenty-first 
century had already been canvassed in the 1990s. Our literature review demonstrates that a substantial body of feminist work in music had been generated in the previous century. Quite reasonably, it had been anticipated that most of the issues to do with women's marginalisation would by now have been solved.

Susan McClary’s overview of feminist work in musicology (1993) declared that a huge amount had been accomplished. Sally Macarthur (2010), however, reflected that from the standpoint of 2010, ' ... what seemed like a future full of hope in 1993 is, perhaps, a shattered dream, for it seems ... that feminist research on women's classical music has all but disappeared' (p. 90). That inequality continues to be a pressing issue for the performance of women's concert music and in need of serious repair echoes recent general data about women in OECD countries (OECD Gender Portal 2017) in which the gender gap in many areas such as education, pay, and full-time employment, is shown to be widening rather than narrowing.

Drawing on data from our literature review and that of a three-part international survey of 71 women composers, we will illustrate that there is still much work to be done in the so-called post-feminist era of the twenty-first century. Some of the literature highlights a significant decline in the amount of contemporary women's music performed on concert platforms in the first decade of the twenty-first century, a situation that continues in the second decade. We also note that there was a concomitant decline in the amount of research conducted on women's music in that period, with a notable increase observed in the latter decade.

Our literature review also indicates a correlation between the amount of research conducted on women's music and that of its performance in the concert hall: when the research tapers off and feminist issues take a back seat, the amount of women's music performed in the 
concert hall also decreases. Furthermore, the reduction of research on women's music together with that of its performance in the concert hall, seems to be influenced by the shift more broadly to neoliberal or post-feminism from second-wave feminism. The implication is that neoliberal feminism, founded on the premise that feminism as it was understood in the 1990s is now over, and that the issues raised by second-wave feminism have been solved. Contrary to this view, our research maintains that there is an ongoing necessity to keep the feminist issues from the past alive in the present day. If the issues continue the pattern of receding and then reappearing, feminist work will continue to perpetuate a circular model of argument about identity politics such that 'what goes around keeps coming around'.

In the mid-to-late twentieth century, a steady stream of feminist work flowing into musicology identified gender inequality as an urgent concern. This work reached a pinnacle in the 1990s (McClary 1991; Pendle 1991; Citron 1993; Solie 1993; Cook and Tsou 1994), with Susan McClary’s Feminine Endings (1991) triggering an outpouring that both polarised musicology and produced a backlash against McClary (see, for example, Van den Toorn 1991; Van den Toorn 1995; Barkin 1992; Higgins 1993; Treitler 1993; Sayrs 1993-4). Paula Higgins $(1993,175)$ states that 'rarely has a musicological publication ignited such volatile scholarly controversy', a view with which Linda Kouvaras (2014) was to later concur, proposing that McClary, 'the groundbreaking-rebel-musicologist' (111), almost singlehandedly pioneered what has since become known as the New Musicology (107). Macarthur (2010, 99-101) examined the oppositional nature of the debate provoked by Feminine Endings, employing the concepts of 'active' and 'reactive' from the philosophy of Deleuze and Guattari. Quoting Spinks (2005, 8), Macarthur (2010, 91) observed that 'an active force becomes reactive when a reactive force manages to separate it from what it can 
do.' She argued that Feminine Endings produced a form of critical work that was unfamiliar to mainstream musicology.

From a position of initial weakness, feminist musicology emerged as a reactive force. With the impact of McClary's book, it was transformed into an active force, turning the tables on mainstream musicology to make it less powerful and more vulnerable. As Macarthur (2010) later noted, however, the reactionary and dialectical character of the debate produced an inevitable re-turning-of-the-tables, with feminist musicology once again positioned as a reactive force. As we will argue in this article, the reactionary character of feminist work, activated by McClary's book and predicated on an active/reactive dialectic, continues to underscore the work on women's music.

A defining feature of McClary's work is its reaction to the prevailing, dominant view that music should be studied as an abstract, autonomous, and self-contained system, aspiring to ‘the condition of the "purely musical”' (McClary 2000, 3). Contrary to this attitude, as Higgins puts it, McClary 'deploys a formidable arsenal of hermeneutic weapons to implode the meaning-laden surfaces of musical texts’ (Higgins 1993, 178), demonstrating that music is not only capable of transmitting knowledge about our social and political worlds but that, in and of itself, it has the capacity to interpret culture. Higgins comments that McClary’s insertion of women into a musicological discourse that is overwhelmingly dominated by the notion of male genius is a revolutionary act (178). However, among the weaknesses of McClary’s work, Higgins identifies the tendency to reinscribe the very stereotypes that she is attempting to erode. 
While a decline in the scholarship devoted to women's music led to a decline in the amount of music composed by women performed in the concert hall in the first decade of the twentyfirst century (Adkins Chiti 2003a; 2003b; Fowler 2006; Hirsch 2008; Macarthur 2010; 2014; Browning 2016), in the second (present) decade, mirroring the 1990s, there is a renewed interest in feminist issues in the scholarly and popular literature (Ambache 2016; Ayres 2015; Bleicher 2015; Browning 2016; Cartwright 2012; Dunphy 2013; Macarthur 2013; Shapiro 2016; Macarthur, Hope and Bennett 2016). This interest has been ignited by the recognition that equality still has a long way to go before being achieved. The recent scholarship has prompted debates (again) about topics that were examined in the 1990s: should we have quotas, women-only music festivals, different selection-criteria for women’s music, and is women's music different from men's music? Are we merely experiencing a recycling of 1990s concerns in the present day or, as Rosalind Gill (2016) argues more broadly, is contemporary feminism much more complicated than it was in its earlier manifestations? If it is more complicated, as we will indicate is the case, how is this reflected in the attitudes of women composers towards their gender?

While it is beyond the scope of the present article to answer these questions, we note that these very questions continue to animate the field of classical music composition and its performance. A finding of our survey of 71 women composers, for example, indicated that gender has a negative impact on their careers, with women composers reporting that they felt discouraged and isolated, were taken less seriously than men, had problems promoting themselves, and were often subjected to sexism, sexual harassment and tokenism. 
We use the concept of the habitus ${ }^{1}$, as conceived by Pierre Bourdieu (1984), to consider the intersection of feminism with gender and, in so doing, to explicitly examine how gender functions as a primary organisational attribute of the field of classical music. Bourdieu's field theory and its accompanying concept of the habitus, allows us to explore the significance of the distinction between male and female. We understand contemporary classical music composition to be a field that encompasses 'the active presence of the whole past of which it is a product' (Bourdieu 1990, 56). In this field, the female (or woman) composer has a distinct presence despite her virtual exclusion in performance venues. This exclusion is grounded in the past, on the false assumptions that historically there have been no great women composers (see, for example, Ladd 1917; Seashore c. 1947; Rubin-Rabson 1973; Gates 1994); and, that if female composers managed to assimilate into the male world of composition, their music would become indistinguishable from that of male composers (see, for example, the discussion of this issue in Macarthur 2002, pp 1-10).

The male/female distinction has animated the field of new music composition since the 1970s. What we want to do, in this article, is to answer the question of how gender impacts on the field of new music composition, and to inquire about the extent to which the presence of women composers and their experiences within the field in the present day have the potential to change the shape of the field itself. We are using the concept of the field as an analytical tool, allowing us to examine how composers and musicologists writing about women composers take up positions within the field.

\footnotetext{
${ }^{1}$ The word 'habitus' is derived from the Latin meaning 'bodily constitution'; it is associated with 'condition, state, dress, get-up, expression, character.'
} 
In our study, the positions and position-takings of our composers, according to the scholarly literature, seem to produce something of a deja vu when compared with the 1990s. The habitus, which goes hand-in-hand with the field, is moulded over a lengthy period of inculcation and becomes formed and durable in adulthood. It accounts for why we take the world for granted (Bourdieu 1990, 56; also see Bourdieu 1993, 29-73) and posits that the dispositions we form become enduring and embedded in the collective unconscious. Life's experiences are ‘internalized as second nature and so forgotten as history’ (Bourdieu 1990, 56). The habitus is thus unconsciously generative.

The habitus plays a vital role in the construction of the gender dispositions of the field of music composition. Accordingly, gender relations are ever present in 'perception, thought and action' (Bourdieu 2001, 8). We agree with Huppatz (2012) that the female habitus is constructed in opposition to the male habitus and that it 'assures consistency in practice over time so that gendered dispositions often appear relatively stable’ (18). The habitus shapes gender 'aspirations according to concrete indices of the accessible and inaccessible, of what is, and what is not "for us"' (Bourdieu 1990, 64). Huppatz says that the 'gender order is particularly entrenched because masculine domination is predominantly legitimated' (19) given that it is lodged 'in a biological nature that is itself a naturalised social construct' (Bourdieu 2001, 23).

As with the class system, Bourdieu says that the primary means by which the gender order is maintained is through symbolic violence (2001) and that a gendered 'vision and division' of the world 'is constructed by those with legitimate authority' (Huppatz 2012, 20). In music, those with legitimate authority are men and this gives rise to a habitus that organises the field of classical music according to male norms. In music composition, women composers 
comprise only twenty-six per cent of the composers represented at the Australian Music Centre (Australian Music Centre Portal 2017), the institutional body responsible for representing professional composers in Australia. This statistic, coupled with the finding above that there has been a decline in the amount of women's music performed in concert venues, suggests that music composition continues to be actively constructed as 'men's work' and as a masculine occupation.

Through the literature review and empirical data, we explore the relationship between gender, and symbolic and cultural capital in music, and investigate the ways in which the female habitus organises itself on feminist principles, postulating, as Gill (2016) does, that postfeminism is deeply enmeshed with neoliberalism, and that a feminist sensibility prevails in the current time. We will suggest that a feminist sensibility also organises the female habitus. With its emphasis on the individual, neoliberalism gives rise to the co-existence of several versions of feminisms that are in tension with one another. We provide an outline of the feminist research in music undertaken during the late twentieth century and demonstrate that it resonates with the literature emerging in the second decade of the twenty-first century. We note that the literature in the present decade has a preoccupation with issues that were addressed in the 1990s, particularly with equality. We then employ Bourdieu's theory of the habitus to understand the gendered experiences of female composers who participated in an international study of women composers. We show that the participants have different investments in gender but that, overall, they reinforce the male habitus given that the female habitus occupies a subordinate position in relation to that of the male.

Following this, we present the findings of our research and show that there is a connection between contemporary feminism and the attitudes held by the participants in our study 
towards gender. Drawing on Bourdieu's theory, which asserts that 'social identity is defined and asserted through difference' (Bourdieu 1984, 172), we embark on a discussion that shows how the female composers in the study classify themselves, as well as others, according to gendered norms and that these perpetuate the social order in music in which the male norm dominates. Following Huppatz, we will argue that any individual practice, action or reaction is always a component of the larger class relations in a given field, and that these practices are not necessarily consciously adopted but are taken up 'outside of discourse and consciousness through bodily "hexis” rather than mechanical learning' (Huppatz 2012, 9; see also Bourdieu 1990, 80).

\title{
Overview of Feminist Work on Music
}

\author{
Post-Feminism and Neoliberalism
}

Gill (2016) uses the term 'post-feminism' to refer to all the possible versions of feminism that co-exist in the neoliberal world of today. Consequently, post-feminism is characterised in several contradictory ways, including: as a backlash against feminism; a time following second-wave feminism; an epistemological break within feminism; an alignment with other “post” movements (poststructuralism, postmodernism, and postcoloniality); and as a relationship to third wave feminism (612-13). Gail Dines (2012) argues that neoliberal feminism's emphasis on the individual - that feminism is something that is specific to each feminist - discourages the possibility of women standing together.

For Dines, neoliberalism thus disempowers the collective and fragments the category of ‘woman’ with the effect of ‘killing off' feminism (Dines 2012). Gill (2016), however, less 
pessimistic than Dines, suggests that despite the existence of multiple versions of postfeminism, two formulations, both of which are enmeshed with neoliberalism, are influential. The first is Angela McRobbie's idea of post-feminism as the 'undoing of feminism' (2009). The second is Gill's own notion that post-feminism is a sensibility rather than a movement that follows second-wave feminism (Gill 2016). While McRobbie (2009) views postfeminism as an ending, Gill argues for its use as a 'critical analytical term that refers to empirical irregularities or patterns in contemporary cultural life, which include an emphasis on individualism, choice and agency as dominant modes of accounting' (Gill 2016, 613). She says that as a concept, post-feminism is still relevant to feminist work. Like Gill, we will suggest that post-feminism, in all its multiple versions, including the idea of its sensibility, is pertinent to our present study and is relevant to the work of women composers.

\section{Probing Feminist Issues in Music Since the 1990s}

Before examining how attitudes to gender by women composers are linked with the idea of post-feminism as a sensibility, we will now sketch an outline of the feminist work that commenced in the 1970s in musicology. McClary’s review essay (1993), which canvasses two decades of work on gender and music while updating an earlier review about women and music by Elizabeth Wood (1980), is a good place to start given that it reflects on the explosion of interest in the field in the early 1990s. McClary points out that in a very short timeframe the achievements of this research were significant: it uncovered a history of women's music that had previously vanished, and it addressed some of the underlying causes for the invisibility of women composers, mobilising the tools of critical feminist and poststructuralist theories for this purpose. The research also drew attention to an issue that polarised musicology. The critical work, which adopted approaches used widely in the 
humanities, some of which was put to work to re-examine the canon and the standard methodologies used in musicology, 'provoked widespread, often bitter debates' (McClary 1993, 399) in a discipline that had long resisted critical agendas of any sort. Here, McClary echoes Joseph Kerman (1985) who asserted that critical thought was virtually absent in musicology and that in this respect it conceptually lagged far behind work in the other arts.

The sturm und drang of the feminist work from the 1990s divided musicology into more subdisciplines, including what in the US was dubbed the New Musicology and in the UK Critical Musicology. It emphasised existing boundaries between historical and analytical musicology and its western classical music repertoire, ethnomusicology and its non-western music, and popular music studies. It also exposed new borders between feminist musicology and mainstream musicology. In the feminist musicological field, further divisions were also in evidence: between liberal and radical feminist musicology (Macarthur 2010, 80-108); and later, between these two versions of feminism and the neoliberal or post-feminist versions (Citron 2004; 2007; Macarthur 2014).

Ellen Koskoff (2005) claimed that the divisions between ethnomusicology and western musicology were credited to the different approaches used by researchers in these fields, arguing that western musicology is grounded in theoretical, text-work while ethnomusicology is focused on empirical fieldwork (implying, perhaps, that it, too, lacked a critical dimension). Koskoff maintained that her own discipline, loosely labelled 'genderist studies in ethnomusicology', is more marginalised than that of comparable work in western musicology. She supports this claim with a tally of articles that were published between 1997 and 2004 inclusive in the peer-reviewed journal, Women and Music: of a total of 46 articles, 
39 (85\%) were devoted to gender and western musicology and 7 (15\%) were dedicated to ethnomusicology.

Our survey of the literature on gender and music would tend to agree with Koskoff's appraisal: indeed, it would suggest that a far lower representation exists for ethnomusicological work. Of the 184 books, book chapters, reports, journals and newspaper articles that we reviewed, including academic and non-academic publications, we found that 5 (3\%) were devoted to ethnomusicological topics. It is important to point out, however, that our present study of women composers is not ethnomusicological in orientation, and nor does it focus on popular music or sound studies. Rather, it only draws on these literatures for the common concerns that they share with the present research.

An issue highlighted in Koskoff's comparison between ethnomusicology and western musicology, however, is that the empirical approaches to studying women in music tend to produce interpretations that reinforce the binary divisions between male and female. This has a resonance with the work of the present international study of women composers, in that the binary division between the male and female habitus is integral to our analysis. However, we will show that a Bourdieusian analysis allows us to interrogate the assumptions that underpin positivist work. In contrast to positivist work, the theoretical text-work of western musicology is focused on eroding binary divisions and warding off the traps of essentialism.

Much of the literature focused on western art music from the 1990s, carried forward into the twenty-first century, has a theoretical emphasis and is fundamentally focused on identity as it relates to gender and sexuality, intersecting with the debates about essentialism and binary thinking (see, for example, Clément 1988; McClary 1991; Soli 1991; Citron 1993; Higgins 
1993; Maus 1993; 2011; Soli 1993; Guck 1994; Hisama 2002; Macarthur 2002; and numerous others). More recent work proposes a new way to think about identity and music, drawing on the immanent thought that characterises the philosophy of Deleuze, and Deleuze with Guattari (Gould 2004; 2009; Kielian-Gilbert 2010; Macarthur 2010; Macarthur, Lochhead and Shaw 2016).

The dominant approaches and emergent themes in the musicological literature since the 1970s can be thus sketched as work that:

1. Focuses on source documentation to assemble a women's music history to uncover the 'who' and the 'what' of that history (Drinker 1977 [1948]; Bloch and Neuls-Bates 1979; Wood 1980; Bowers and Tick 1986; Cohen 1987 [1981]; Jezic 1988 [1994]; Pendle 1991; McClary 1993; Sadie and Samuel 1994);

2. Engages with prevailing views based on their unquestioned biological, deterministic assumptions that there have been no great women composers (and never will be) and that women’s music is inferior to men’s music (Ladd 1917; Seashore c.1947; RubinRabson 1973; Tick 1975; Gates 1994; 2006; Thompson 2015; Moh-Pietsch 2016; also see Nochlin 1973);

3. Concerns itself with egalitarianism as core to the liberal feminist endeavour, aiming to address the inequities between men and women in music (Mageau 1991; Radic 1991; Rogers, Baldcock and Mulligan 1993; Macarthur 1997; Adkins-Chiti 2003a; 2003b; Fowler 2006; Hirsch 2008; Cartwright 2012; Dunphy 2015; Macarthur 2013; Ayres 2015; Bleicher and Bain 2015; Criado-Perez 2015; Ambache 2016; Browning 2016; Macarthur, Hope and Bennett 2016; Wright 2016; Larson [undated];

4. Applies the tools of radical feminist theory to create a reactionary discourse to the suggestion that women's music is inferior and seeks, instead, to posit women’s music 
as different from men’s music but no less worthy (Rieger 1981; 1992; Ecker 1985; McClary 1991; Cox 1991; Solie 1993; Dunn and Jones, 1994; Hontos 2001; Hisama 2002; Macarthur 2002; Redhead 2015; Rusak 2005);

5. Produces a feminist music criticism that opens up a discipline of study in musicology that is engaged with issues of gender and sexuality (Wood 1980; McClary 1993; Brett, Wood and Thomas 1994; Pendle 2005; Morris 2008-09);

6. Engages with issues produced by the egalitarian and radical feminist projects, with their essentialist overtones, and seeks other ways to move the debates about identity out of the essentialist paradigm (Cusick 1994; 1997; 1999; Kielian-Gilbert 2010; Maus 2011; Macarthur, Lochhead and Shaw 2016);

7. Seeks to explain the ways in which composer identities have changed over time (Macarthur 2010; Hulse 2015); and

8. Shifts from representational thought, which locks identity into hierarchical categories, to propose a new way of thinking that draws on the immanent thought of Deleuze to promote a different way of theorising identity in which theories of 'becoming' (or futurity) take precedence over 'being’ and the here and now (Gould 2004; 2009; Macarthur 2010; Macarthur, Lochhead and Shaw 2016).

From its earliest iteration to the present day, feminist musicology - regardless of its orientation to western musicology, ethnomusicology, sound studies or popular music studies - is situated on the periphery of institutional musicology. This may seem surprising given McClary’s proclamation in the 1990s that mainstream musicology had been permanently transformed by its encounter with feminism. She also inferred that feminist work at that time was becoming mainstreamed (1993). McClary was optimistic that in the future the discrimination against women composers would be changed for the better, as she put it, 
'beyond our wildest hopes’ $(1993,420)$. In the first two decades of the twenty-first century, however, we find that field has not been transformed enough, with some of the literature - as discussed above and immediately below - suggesting that the performance of women's music on the concert platform is in decline.

Several studies in the academic and popular presses since the turn of the twenty-first century support this claim with the most notable being:

- Patricia Adkins-Chiti (2003a; 2003b), whose surveys of the number of works by women composers represented in orchestras, festivals and new music ensembles in Europe shows that it constitutes $2 \%$ of the works performed, leading her to conclude that the gender gap is widening.

- Jennifer Fowler (2006), whose analysis of the British Proms from 1989 to 2006 showed that women's music constituted $1 \%$ of the works performed.

- Lisa Hirsch’s survey (2008), which noted that women's music constituted 2\% of the music performed by the League of American Orchestras but that a better picture emerged with their representation by contemporary music ensembles in which it ranged from $0.5 \%$ to $22 \%$.

- Sally Macarthur (2010; 2014), whose earlier study (1997) fed into her surveys of new music ensembles in Australia to argue that the situation is worse in the second decade of the twenty-first century than it was in the 1990s, with only $11 \%$ of women composers being represented by contemporary performance groups in 2013 compared with 35\% in 1995.

- Jan Browning (2016), whose study suggests that women composers comprise 25\%$29 \%$ of composition students in Australia yet only $12 \%$ of women's music is performed. 
- Articles in the popular press, which paint a bleak picture, showing that women continue to struggle to have their music equally represented with men in concerts (for example, Dunphy 2013; Ayers 2013; Macarthur 2013; Henderson 2015; and Macarthur, Hope and Bennett 2016).

The Rise and Fall, and the Rise (again) of Feminist Research in Music

The discrimination against women's music in the concert hall seems to be reinforced by a concomitant reduction in the amount of research and commentary devoted to the issue in the academic and popular presses since the 1990s. Figure 1 illustrates the abundance of work that had been conducted in the field in the first few years of the 1990s and its decline in the latter part of that decade and in the first decade of the twenty-first century. This work appears mostly in the academic press.

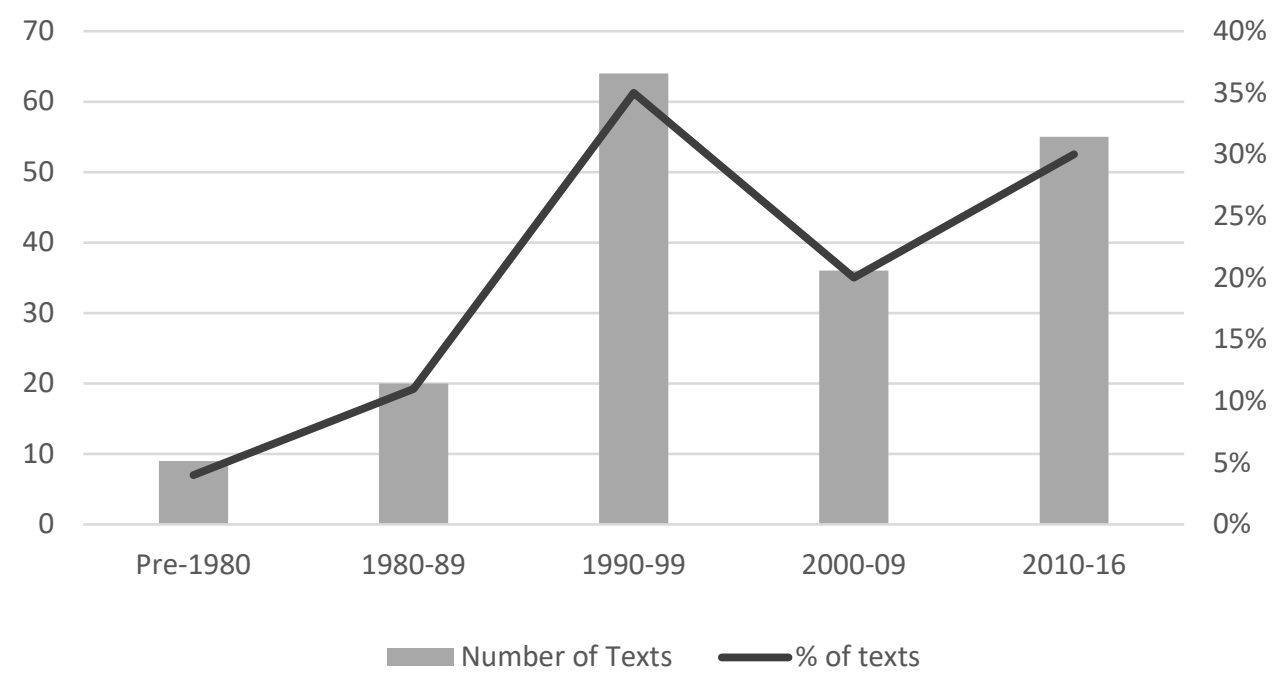

Figure 1: Number and Percentage of Texts on Women in Music Pre-1980 to 2016

\section{Analysing the literature}


A total of 184 texts was sourced from the literature and reviewed. The texts were divided into five timeframes: preceding the 1980s; the 1980s; the 1990s; the first decade of the twentyfirst century; and from 2010-2016. More than a third - 64 of 184 texts (35\%) - of the reviewed literature was published in the first half of the 1990s. The amount of research undertaken in the first decade of the twenty-first century then dramatically decreased with the number of texts reviewed being pared back to 36 (20\%). Figure 1 also indicates that between 2010-2016 inclusive, the number of texts reporting on women's music increased again to almost a third - 55 of 184 texts (30\%) - suggesting a parallel interest in women’s music in the current decade with that of the first half of the 1990s. This leads us to speculate that before the end of this second decade it is likely that there will be an even greater increase in the amount of work undertaken in this field.

Figures 2 and 3 represent the volume of writing about women and music on a year-by-year basis for the 1990s (Figure 2) and the second decade of the twenty-first century (Figure 3). The review of the published work on women's music in the 1990s in Figure 2 shows a highpoint in 1994 with almost one quarter of the texts reviewed - 15 of a total of 64 texts (23\%) generated in that year. Thereafter a sharp decline is in evidence in the second half of the 1990s: in 1995, only 3 (5\%) texts were published; and in 1996, only 2 (3\%) texts were published. In 1999, an increase is noted with the publication of 8 (13\%) texts. It is not until the second decade of the twenty-first century that the literature on women's music begins to increase as shown in Figure 3.

Figure 3 has a similar pattern to that shown in Figure 2, with the second decade of the twenty-first being a mirror of the 1990s. In the second decade of the twenty-first century, however, the highpoints for the published work in the field are the years 2015 and 2016. Of a 
total of 55 texts reviewed for this decade, 14 (26\%) are published in 2015 and 16 (29\% are published in 2016. It should be noted that while the research generated in the 1990s appears largely in the academic press, much of the research reviewed in the second decade of the twenty-first century appears in the popular press. However, most articles in the popular press have been written by specialists who have also presented their findings in academic forums.

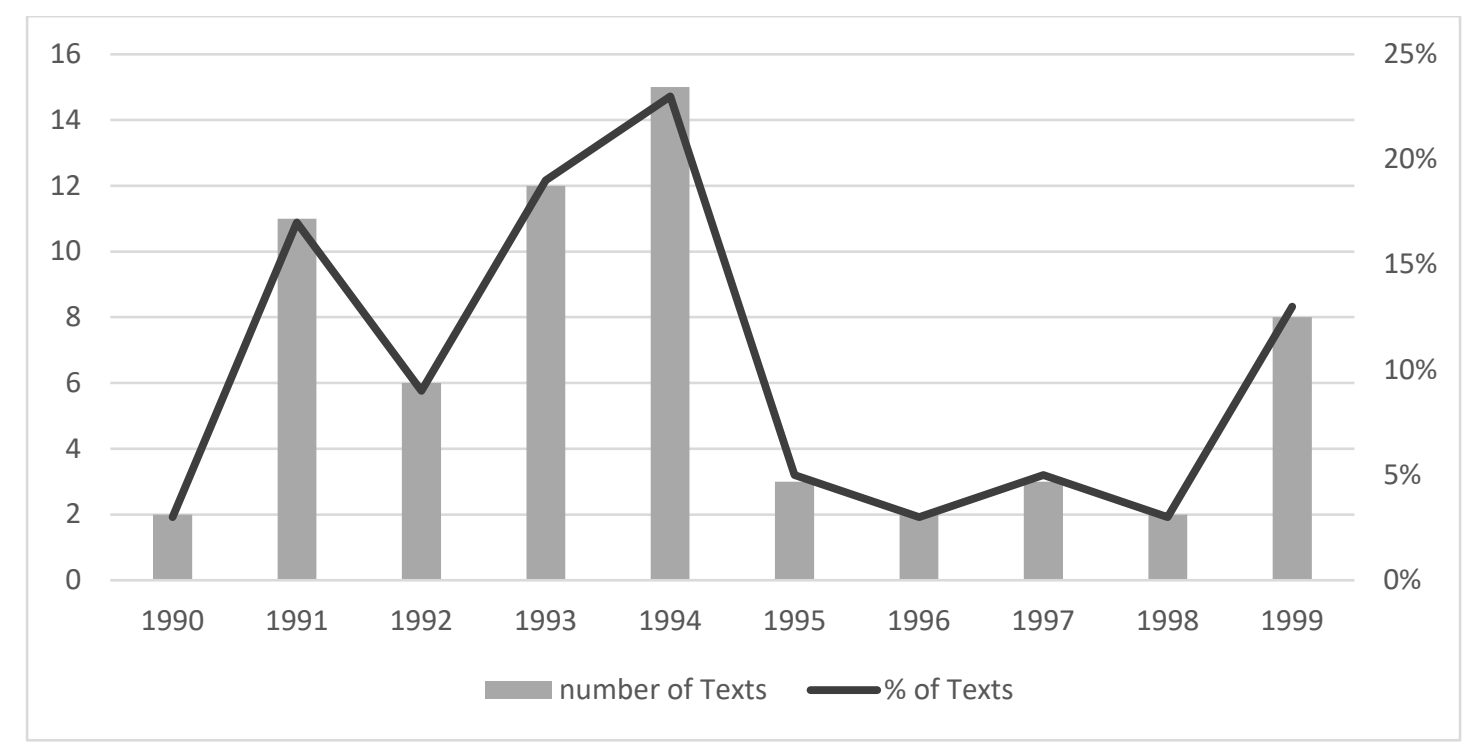

Figure 2: Number and Percentage of Texts on Women in Music 1990-1999

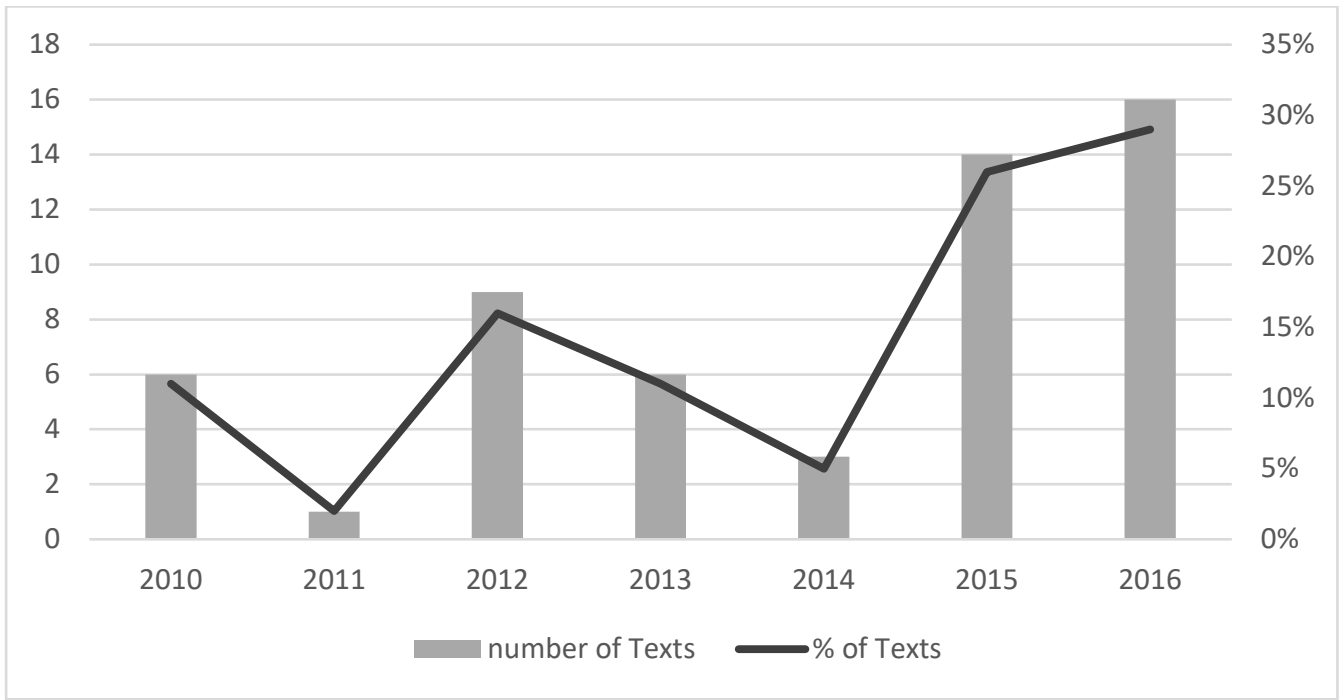

Figure 3: Number and Percentage of Texts on Women in Music 2010-2016 
The extant scholarship on women in music overall has identified several important avenues for research. These have included: archival research, which has continually added more women to the history of women’s music and generated biographies and bibliographies; analytical research, which has focused on analysing the music of women composers; and the creation of scholarly editions of women's music, which has aimed to make women's music readily available as published scores, thus enabling its performance and recording. The research in the field has also identified how patterns of discrimination arise and analysed the ways in which discrimination has curtailed women composers' career opportunities. Finally, the research focused on living composers has concluded that women continue to struggle to have a presence in the field of musical composition.

\section{Gendered habitus in the practice of women composers}

Having completed our analysis of the literature, we sought to investigate continued gender inequities in contemporary composition through a series of three surveys. These were designed to elicit data on aspects of women composers' careers including career trajectories,

time allocation, experiences, opportunities and challenges. The surveys contained both closed and open-ended questions and they were answered online using the survey platform Survey Monkey. Participants were recruited using social media networks, word-of-mouth and email. Participation was voluntary and unremunerated, and survey answers were de-identified from the participants' personal and contact information.

\section{Sample}


The sample consisted of 71 women composers, 94\% of whom had undertaken formal postsecondary studies in music or composition. Since the age of 18, participants had composed for between 0 (new entrants) and 60 years, with an average of 24 years. The span of years during which composers had derived an income from their composition ranged from 0 to 55 years with an average of 16 years. Few participants worked full time in composition, with an average of between 10 and 19 hours spent in composition work each week. The composers held an average of 2.6 paid roles; 64\% had more than one paid role. Although most responses were from Australia, there was a significant international representation from North America and Europe.

\section{Findings}

The findings reveal the belief of most women composers that gender has impacted the characteristics of their work and their career progression. Moreover, the composers report that this impact continues unresolved. Table 1 outlines the main themes arising from the data; these are then discussed in turn.

Table 1: Themes in the Findings on Perceptions of Gender by Women Composers

\begin{tabular}{ll}
\hline Theme & Description \\
\hline $\begin{array}{l}\text { Impact of gender on career as a } \\
\text { composer }\end{array}$ & $\begin{array}{l}\text { Gender impacts career negatively. Women reported that that they had } \\
\text { have been discouraged; were isolated; were taken less seriously then } \\
\text { men; had problems promoting themselves; and were obliged to contend } \\
\text { with sexism, sexual harassment and tokenism. }\end{array}$ \\
\hline $\begin{array}{l}\text { Unique experiences of women in } \\
\text { music }\end{array}$ & $\begin{array}{l}\text { Motherhood emerged as a singularly unique experience that rebounded } \\
\text { on women composers' careers. Women related motherhood with not } \\
\text { being taken seriously; being ignored; being less confident than men; and } \\
\text { being compelled to deal with biases, stereotypes and discrimination. }\end{array}$ \\
\hline $\begin{array}{l}\text { Lack of women teachers, role } \\
\text { models and music composed by } \\
\text { women }\end{array}$ & $\begin{array}{l}\text { Participants noted a lack of women teachers and role models, and the } \\
\text { underrepresentation or absence of work composed by women: for } \\
\text { example, within the set works during undergraduate study. }\end{array}$ \\
\hline $\begin{array}{l}\text { Support from and to other women } \\
\text { composers }\end{array}$ & $\begin{array}{l}\text { Support was identified as very important. Women composers supported } \\
\text { one another through professional encouragement, shared opportunities, } \\
\text { informal mentorship, peer networks, friendships, recommendations for } \\
\text { work, and networking via social media. }\end{array}$ \\
\hline
\end{tabular}




\begin{tabular}{ll}
\hline $\begin{array}{l}\text { Access to the same networking } \\
\text { opportunities as men }\end{array}$ & $\begin{array}{l}\text { Informal general composer networks were commonly reported as bring } \\
\text { closed to women or difficult for women to access. }\end{array}$ \\
\hline
\end{tabular}

\section{Music Composition as a Gendered Occupation}

Our research shows that most participants believed their gender had had a significant impact on their compositional careers: 41 composers (58\%) reported a negative impact and five composers (7\%) reported a positive impact. Of the negative responses, many composers explained that they sew their gender as a disadvantage in what they described as a maledominated environment. They also perceived that they had fewer opportunities and were taken less seriously, as the following response indicates:

Not being taken seriously, unconscious gender norms that persist even with men and women who try to be feminist and egalitarian, having and raising children and the time, employment and opportunities that slip by during, as an older woman, being seen as "dottering" rather than the "distinguished" label that is usually applied to older men composers. (Respondent 8)

Women composers reported awkwardness in successfully promoting themselves, and aligned this with gendered norms and male-dominated networks:

I think that it [my gender] has made it harder - mainly because you have to be prepared to promote yourself. This is seen by some as not feminine, and as I read somewhere, you 'pay a likability tax'. This was helpful for me to realise and I decided it meant so much to me that I would take any consequences such as unpopularity. The disapproval interestingly is often from other women. (Respondent 2)

It is much harder to obtain funding and performances. ... There is a tendency for the more powerful men to prefer to promote other men. (Respondent 12)

Motherhood, maintenance of a work-life balance, lack of confidence and fewer commissions or opportunities were also significant challenges reported by the participants: 
As a mother: time management ... is, strangely, better overall than before parenting. While household duties are fairly balanced here, our toddler is very much attached to me. This makes it hard to attend events, travel, and stay engaged with the community face-to-face. (Respondent 37)

Again, gendered norms were a facet of the responses.

Oddly enough, for me personally they're mostly challenges from within. I feel unready, unworthy, underqualified, reticent, all the time. I'm fairly sure that I would feel less so if I'd been raised a man. (Respondent 29)

Five participants reported that they had been actively discouraged from composing, and four others wrote that they were challenged by the stereotypes about women and felt excluded because men "gravitate" towards other men.

It's very hard to be taken seriously when you're told you're 'a housewife with a hobby' and that composition is not a vocation for women. (Respondent 58)

Other difficulties reported by the participants include: intimidation and tokenism due to the scarcity of women composers; bias from others who assumed they were hired because of their gender; isolation or loneliness; lack of support; negative perceptions of feminism; sexual discrimination or harassment; financial insecurity; lack of role models or mentors; antagonism from other women; underrepresentation in particular genres; and age discrimination. Respondent 20, for example, stated that:

At the after-concert receptions men talk business to other men, but as a woman you always have to fight not be flirted at but taken as a serious conversation partner. You have a great concert and later you are told: 'We talked about you, your nice piece, but also that you look amazing on stage’. (Respondent 20)

If a woman is successful or wins a prize very easily you hear the male colleges saying: 'Yes, she got it because she is a woman.' If a woman wants to try something she hasn't done before no one is going to trust her that she can do it. If she was a man 
it would be way more likely someone would. If a woman is attractive most men think they have the right to flirt instead of discuss things. (Respondent 20)

Respondent 23 made a similar point, writing that:

If you're assertive, you're bitchy, if you're not, you're ignored; sexual harassment; the talking over and 'mansplaning'. There can also be the preconception that as a woman, you write 'pretty music', and even if it's not true, it won't be taken as seriously as male colleagues who write in a similar style. (Respondent 23)

Unique experiences of women in music

Of 65 participants who answered this question, 41 (63\%) reported experiences they considered to be unique to women in music. Motherhood and dealing with caring and household duties while sustaining a career in composition were mentioned frequently. One participant mentioned that her demanding career made her decide not to have children.

Women have different life experiences to men, and it follows that women in music would have a perspective that would be unique. For example, trying to juggle childbearing and family responsibilities at a critical point in their careers when their male peers are 'emerging'. (Respondent 25)

Women composers also reported that they were not taken seriously or were ignored. Some women had experienced discrimination and sexism and had to contend with biases and stereotypes. They also reported low levels of confidence. Indicative comments are included here:

I was put forward for a prize at a festival and a male festival director vetoed my place in favour of a man. This actually happened to me twice. (Respondent 12)

(I'm) being seen as meek or uncertain because I am not as demonstrative as my male colleagues. (Respondent 23) 
Not being taken seriously, being told that only the male bird sings, being told the concert series already includes 3 women and 97 men and that is all the women they have room for. (Respondent 60)

Reception is completely different. There is surprise that a woman might be successful, and questions tend to be less about form and structure and more about preconceptions about women's lives. (Respondent 12)

Being told you write good music for a girl. Mostly dealing with unfounded assumptions about us, and fighting to be represented equally re opportunities. (Respondent 14)

Despite experiencing acceptance and a level of success, I still feel like there can be a pocket of the classical community that is dismissive (to varying levels - consciously patronising, or subconsciously through small comments, etc.) of the work of composing women. My experience has included coming to terms with this attitude and how to respond. Currently my response is to treat it like any backward-thinking attitude: as not worthy of debate... (Respondent 37)

Lack of role models: women teachers and work composed by women

Participants also noted the lack of women during their composition training. They mentioned the underrepresentation of both women teachers and of work composed by women. Of the 70 women who answered this question, 37 (53\%) mentioned having had no women teachers, while $12(17 \%)$ reported that between $1 \%$ and $10 \%$ of their teachers had been women. Similar findings were obtained when questioning the participants about music composed by women with 36 (52\%) participants reporting that music composed by women was rarely, if ever, represented. Asked where they would find music composed by women, the composers mentioned that it could be sourced in concert programs (32 respondents), mentioned in discussions (27 respondents), found in library collections (24 respondents), or used as exemplars or texts (19 respondents). 
Asked to describe the kind of supports they accessed, women composers emphasised professional encouragement from other women, peer-derived opportunities and insights, and networking. Frequent mentions were made of communities of practice accessed via social media, websites, and other online networks. Indicative responses follow.

I am extremely grateful for the 'women composers' group on Facebook - it is a place where you can talk about all sorts of things, share your works, your frustrations, your questions and just generally feel like you're not alone. (Respondent 4)

We all talk about the issues we deal with. When asked to recommend composers for projects, I always try to make sure that women are being recommended. (Respondent 11)

I am not in close contact with other women composers, though I receive support from female colleagues from other fields (writing): Talking about work processes, motivating each other, talking about patriarchal structures and how to deal with them. (Respondent 20)

Participants also mentioned specific ways in which they supported other women composers, such as mentorship on how to negotiate a gendered environment, as seen above. Women also attended one another's performances and they would share and 'like' women's music via social media. Women used these avenues to raise awareness of women composers and to actively promote their work. Two examples follow.

I try to do lots of things to help champion and support my colleagues. Sometimes it's helping answer questions or adding my thoughts/experiences to questions on the Facebook 'Women Composers' groups. Other times I am forwarding composing commissioning opportunities on to my local colleagues. I put my fellow composers' names forward for all sorts of opportunities, and try to help connect commissioners with the right composer. We attend each others' concerts as much as we can as well. (Respondent 4) 
I am involved in running a women composers' festival. I am actively trying to get teachers at my school to perform and teach pieces by women and other underrepresented groups by compiling databases of repertoire and organizing special recitals, and I mentor young composers. (Respondent 16)

Access to the same networking opportunities as men

Participants were asked whether they felt they had equitable access to networking opportunities. Thirty-five of the 67 women who answered this question reported that this was not the case and that the situation disadvantaged women. Many women emphasised that much gender bias was an unconscious feature of a normalised gendered environment. They also pointed to sexualised behaviours, to the blurred boundaries between professional and social networks, and to the difficulties of other minority groups. However, many of the formal and informal networks enjoyed by men were closed to women or were difficult to access.

On the surface, yes, it appears that the opportunities are the same in my country. However, when I've been to conferences about composition, there is still a palpable 'old boys"' network going on, even if the men themselves are unaware of it. They ask questions the most and are more aggressive about asking, for example. There are almost always more men on panel discussions than women, and almost always more men than women conductors featured. (Respondent 21)

Networking opportunities are by their very nature disadvantageous towards women and minorities. These are informal networks based on prior access to power - I didn't go to the same private boys' schools or study at the same institutions. Part of my own challenge is not just being a woman, but being a new immigrant. It compounds the lack of access to these informal networks. Another aspect is that when I was younger it was hard to counter the blurring of lines between the socializing and the sexualisation of young women artists. (Respondent 30)

Men enjoy hanging out with one another and including one another in their social activities. They simply forget that women are potentially musical equals. This means that women need to work extra hard to stay included as a composer/performer and professional equal. (Respondent 46) 
Moreover, participants stressed that caring responsibilities were often at odds with the demands of effective networking. Women reported that their networks were less developed, and some participants mentioned that because of the harsh competition, women were not always supportive towards other women.

The women's club is not as old as the male one, many women don't want to share and exclude other females. (Respondent 18)

Women are unequally represented in certain music genres

Sixty-three of the 69 participants felt that women were unequally represented in certain genres of music. The genres deemed to be the most challenging with respect to equity were electronic music, jazz, contemporary classical and contemporary music genres. Other genres seen in these negative terms mentioned included improvised music, church music, rock, pop, music technology, sound art, heavy metal, hip hop, and world music.

\section{Discussion: Gender Capital in Music Composition}

The findings illustrate that the reproduction of a gendered habitus - the practices and dispositions of composers - is in evidence in the field of music composition. Participating women composers tended to struggle for recognition (symbolic capital) and many had negative attitudes towards their gender in relation to their work. Gender is thus shown to have a significant impact on the participants' careers and lives.

From a Bourdieusian perspective, the data demonstrate that women composers tend to be disadvantaged in relation to their male counterparts when seeking to obtain prestige and recognition for their work. This disadvantage relates to the importance of networks, from 
which many women felt isolated. Music work is characteristically precarious, featuring multiple concurrent roles, strong competition and networked forms of recruitment; yet, as voiced by the women composers, these networks can be both discriminatory and exclusionary (see also Smith and McKinlay 2009). We emphasise that networks are not only important for recruitment; they are also central to knowledge and to learning, which in music are often embedded in social interaction and learning communities (Comunian, Gilmore and Jacobi 2015). Mason $(2013,21)$ emphasises that a field is 'a network of connections, which operate within it and extend beyond its boundaries'. To be isolated from networks, then, is to be less visible in the field itself: less connected with opportunities for work and more reliant on formal, online and less directly applicable knowledge and learning.

The field of music composition, as discussed earlier, is hierarchically organised in terms of the gender order: the field is dominated by men and thus configured according to male norms. According to Bourdieu, as summarised by Huppatz, 'the strong connection between positions and dispositions makes it very difficult for masculine occupations to accept women’ (Huppatz 2012, 29; Bourdieu 2001, 96). Successful women composers are understood in terms of what Bourdieu calls subordinate elites: women pay a price for their work as composers, especially in terms of its conflict with their family life or other demands that would otherwise disqualify them from full participation (Bourdieu 2001, 92-3; see also Huppatz 2012, 28).

According to Bourdieu's theory, women who work in male-dominated occupations struggle for success when compared to women who work in female-dominated occupations, such as the caring professions (for example, nursing and teaching), which is work that Bourdieu views as an extension of women’s domestic functions (Bourdieu 2001, 95). In male 
dominated professions, Bourdieu theorises that 'women cannot have authority over men and so men are more likely to be promoted to positions of authority', and that men 'monopolise “technical objects and machines”' (Bourdieu 2001, 95). This gives rise to a heightened sense of gendered segregation in the field of musical composition and produces unequal relationships between men and women. As Huppatz comments, women’s career choices are shaped by this relationship. In music, this might give rise to the situation in which many more women composers than men work in community music settings or in schools, where their creative work is presented in an amateur context.

While the participant composers were not explicitly asked about their attitudes to feminism, our analysis shows that there is nonetheless a strong connection between feminism and the gendered female habitus. The gendered habitus of the participants predominantly reproduces a 1990s version of equality feminism and tends to support the kinds feminism circulating in the current time as identified by Gill (2016) in which they are being given a new visibility (615). Our data suggest that women composers have a preoccupation with women's representation in the field of music composition and they tend to recycle 'a restricted and predictable set of topics related to ‘positive discrimination’ (Gill 2016, 615). The participating composers overwhelmingly saw the need for quotas.

\section{Conclusion}

In this article, we presented findings from a two-phase study which first analysed 184 texts within the extant literature and then sought to understand the themes and emphases of these texts through a survey of 71 women composers. We argued, drawing on Bourdieu's theory of the field and habitus, that music composition is predominantly a male occupation, making it 
difficult for women composers to be accepted and taken seriously. These concepts led us as observers to notice that the habitus of the field of new music composition in the 1990s and that of its manifestation in the present day is marked by similar positions and positiontakings. Specifically, we noted a heavy investment in equality through which it was hoped that discrimination would be erased; maintaining a separation between the male/female distinction to argue for the distinctiveness and uniqueness of women composers; an inability to move out of binary thinking; and yet, paradoxically, a recognition that the gender distinction is nonetheless a contested and fluid site.

We found that female composers have different investments in gender, but because the female habitus occupies a subordinate position in relation to the male habitus, like its manifestation in the 1990s, it continues to reinforce the dominance of the male. The findings of the study also intimate that there is a connection between contemporary feminism and the attitudes towards gender held by the participants, specifically in relation to "recycling” topics related to positive discrimination. Our study thus supports the view that female composers classify themselves, and others, according to gendered norms. These norms perpetuate the social order in music, in which the male norm dominates.

Here, we return to the importance of active networking for initiating, developing and sustaining careers in music. As discussed, music networks can be both discriminatory and exclusionary; however, as Blair (2009) suggests, network boundaries change within a process that is conscious, informal and instrumental. Individual actions within these networks are a complex interaction between composers' subjective understandings of their individual position and the constraints and opportunities presented by their objective social position. As 
such, gendered norms can be both perpetuated and challenged by individual actions and, in turn, their position in the economic and political fields of power (Hesmondhalgh 2016).

Looking forward, we ask how women composers might be better located to overcome a social order which places them in a subordinate position predicated on gender. We suggest that change in the habitus of composers needs to be sufficient that it changes the field itself. Fields such as that in classical music composition are characterised by an orthodoxy (male norms) and a heterodoxy (female heretical challengers who seek to change the field). Fields are the 'active presence of the whole past'. As such, we contend that change needs to be both autonomous — from inside the field and from lived experience, and heteronomous — from outside the field and reconceptualising experiences in the past.

The assumptions about female invisibility in music composition has permitted mainstream work in musicology to think of music as a male domain and to produce a history that obscures or completely excludes women's contributions. However, this perception of music composition has been disproved through the presentation of historical evidence that women composers have existed for as long as composers who are men (see, for example, Pendle 1991) and that their difference, as argued by some (for example, Rieger 1992; Macarthur 2002; Hisama 2002), is not necessarily based on the deep-seated belief that their music is inferior. In fact, it is this perceived difference, we argue, that has kept the distinction alive in feminist scholarship since the mid-to-late twentieth century and, similarly, in the broader work on gender and music. 
Whilst the past cannot be changed per se, the way in which people make meaning of the past is founded on the way in which the past is experienced in the present. As such, the solution lies not only in composers and other agents changing the lived experience of composers but also in how the past is presented, discussed, reported and taught.

\section{Funding}

This research was partially supported by the Junior Professor Award from the Federation Nationale pour l'Enseignement de la Gestion des Entreprises (FNEGE) in France, which was awarded to the fourth author, Sophie Hennekam.

\section{References}

Adkins Chiti, Patricia (2003a), 'Cultural Diversity-Musical Diversity: A Different VisionWomen Making Music’, 1-9 (Accessed 30 October 2016), http://www.imccim.org/mmap/pdf/prod-chiti-e.pdf

Adkins Chiti, Patricia (2003b), 'Secret Agendas in Orchestral Programming', 325-360 (Accessed 30 October 2016), http://www.culturegates.info/down/secret_agendas.pdf Ambache, Diana (2016), 'Some animals are more equal than others: gender balance in classical music', Classical Music, Issue 1020: 28-28.

Australian Music Centre Portal (2017). (Accessed 30 April 2017), Male versus Female Represented Composers, http://www.australianmusiccentre.com.au/artists Ayres, Emma (2015), ‘Can you name a female composer?’, Engine Room Blog (Accessed 28 March 2015), http://about.abc.net.au/2013/06/can-you-name-a-female-composer/ 
Blair, Helen (2009), 'Active networking: Action, social structure and the process of networking' in McKinlay, Alan and Smith, Chris (eds.), Creative Labour: Working in the creative industries. Basingstoke: Palgrave Macmillan.

Bleicher, Natalie and Bain, Vicki (2015), Equality and Diversity in New Music Commissioning: New Music Commissioning in the UK. British Academy of Composers, Songwriters and Authors (Accessed 30 October 2016), https://basca.org.uk/newsletter/BASCA_Music-Commissioning.pdf

Bloch, Adrienne Fried and Neuls-Bates, Carol (eds) (1979), Women in American Music: A Bibliography of Music and Literature. Westport, Conn: Greenwood Press.

Bourdieu, Pierre (1984). Distinction: A Social Critique of the Judgement of Taste. Trans. Richard Nice. London: Routledge.

Bourdieu, Pierre (1990), The Logic of Practice. Trans. Richard Nice. Cambridge: Polity Press in assoc. Basil Blackwell.

Bourdieu, Pierre (1993), The Field of Cultural Production: Essays on Art and Literature. Ed. and intro. Randal Johnson. Cambridge: Polity Press in assoc. Basil Blackwell.

Bourdieu, Pierre (2001), Masculine Domination. Trans. Richard Nice. Cambridge: Polity Press.

Bowers, Jane, and Tick, Judith (eds) (1986), Women Making Music: The Western Art Tradition, 1150-1950. Urbana and Chicago: University of Illinois Press.

Browning, Jan (2016), Equal Arts: Discussion Paper. Melbourne: Victorian Women’s Trust.

Cartwright, Joan (2011), ‘Conscious Inclusion of Women Musicians’, Gender Studies 11/Supplement: 235-242.

Citron, Marcia J. (1993), Gender and the Musical Canon. Cambridge: Cambridge University Press. 
Citron, Marcia J. (2004) ‘Feminist Waves and Classical Music: Pedagogy, Performance, Research’, Women \& Music, 8 (2004): 47-60.

Citron, Marcia J. (2007), 'Women and the Western Art Music Canon: Where are We Now?', Notes 64/2: 209-15.

Clément, Catherine (1988), Opera, or the Undoing of Women, trans. Betsy Wing. Minneapolis: University of Minnesota Press.

Cohen, Aaron (1987 [1981]), International Encyclopedia of Women Composers. 2nd ed., rev. and enl. 2 vols. New York: Books and Music.

Comunian, Roberta, Abigail Gilmore and Silvie Jacobi (2015), 'Higher education and the creative economy: Creative graduates, knowledge transfer and regional impact debates’, Geography Compass 9/7: 371-383.

Cook, Susan C. and Tsou, Judy J. (eds) (1994), Cecilia Reclaimed: Feminist Perspectives on Gender and Music. Urbana and Chicago: University of Illinois Press.

Cox, Renée (1991), 'Recovering Jouissance: An Introduction to Feminist Musical Aesthetics’ in Pendle, Karin (ed.), Women and Music: A History. Bloomington and Indiannapolis: Indiana University Press, 331-340.

Cusick, Suzanne (2009), Francesca Caccini at the Medici Court: Music and the Circulation of Power. Chicago: University of Chicago Press.

Cusick, Suzanne G. (1994), On a Lesbian Relationship with Music: A Serious Effort Not to Think Straight’' in Brett, Philip, Wood Elizabeth, and Thomas, Gary C. (eds), Queering the Pitch: The New Gay and Lesbian Musicology. New York and London: Routledge, 67-83.

Cusick, Suzanne G. (1999), 'Performing/composing/woman: Francesca Caccini meets Judith Butler' in Macarthur, Sally and Poynton, Cate (eds), Musics and Feminisms. Sydney: Australian Music Centre, 87-98 
Dines, Gail (2012), 'From the Personal is Personal to the Personal is Political: NeoLiberalism and the Defanging of Feminism', [lecture]. (Accessed 1 May 2017), http://www.youtube.com/watch?v=kDcTt0emXhE,

Drinker, Sophie H (1977 [1948]), Music and Women: The Story of Women in Their Relation to Music. Washington, DC: Zebger.

Dunn, Lesley C. and Jones, Nancy A. (eds) (1994), Embodied Voices: Representing female vocality in western culture. Cambridge: Cambridge University Press.

Dunphy, Melissa (2013), ‘I am a woman. I am a composer. I am a woman composer’, Blog, 3 May (Accessed 26 September 2015), http://blog.melissadunphy.com/2013/05/i-am$\underline{\text { woman-i-am-composer-i-am-woman.html }}$

Ecker, Gisela (ed.) (1985), Feminist Aesthetics. Trans. Harriet Anderson. London: Woman’s Press.

Fowler, Jennifer (2006), 'Where are the Women?’, Music Forum, 13/1: 24-25

Gates, Eugene (1994), 'Why Have There Been No Great Women Composers? Psychological Theories, Past and Present', Journal of Aesthetic Education, 28/2: 27-34.

Gates, Eugene (2006), ‘The Woman Composer Question: Philosophical and Historical Perspectives', The Kapralova Society Journal, 4/2: 1-11.

Gill, Rosalind (2016), 'Post-postfeminism?: new feminist visibilities in postfeminist times’, Feminist Media Studies 16/4: 610-630.

Gould, Elizabeth (2004), 'Feminist theory in music education research: grrl-illa games as nomadic practice (or how music education fell from grace)', Music Education Research, 6/1: 67-79.

Gould, Elizabeth (2009), 'Women Working in Music Education: The War Machine’, Philosophy of Music Education Review 17/2: 126-143. 
Guck, Marion A. (1994), 'A Woman's (Theoretical) Work', Perspectives of New Music 32/1: 28-43.

Henderson, Moya (2013), 'Music bosses remain deaf to distortion that gender discrimination creates on stage', Sydney Morning Herald. 11 October. (Accessed 26 September 2015), http://www.smh.com.au/comment/music-bosses-remain-deaf-to-distortion-that-genderdiscrimination-creates-on-stage-20131010-2vb09.html.

Hesmondhalgh, David (2006), 'Bourdieu, the media and cultural production', Media, Culture \& Society 28/2: 211-231.

Higgins, Paula (1993), 'Women in Music, Feminist Criticism, and Guerrilla Musicology: Reflections on Recent Polemics', 19th Century Music xxvii/2: 174-92.

Hirsch, Lisa (2008), ‘Lend Me a Pick Ax: The Slow Dismantling of the Compositional Gender' (Accessed May 2008), New Musicbox: The Web Magazine from the American Music Center, http://www.newmusicbox.org/article.nmbx?id=5576

Hisama, Ellie M. (2002), Gendering Musical Modernism: The Music of Ruth Crawford, Marion Bauer, and Miriam Gideon. Cambridge: Cambridge University Press.

Hontos, Margaret Ellen (2001), The Feminine Voice: Narrative and the contemporary woman composer, PhD Thesis, University of California, Los Angeles.

Hulse, Brian (2015), 'Becoming-Composer', Perspectives of New Music 53/1: 219-237. Huppatz, Kate (2012), Gender Capital at Work: Intersections of Feminity, Masculinity, Class and Occupation. New York: Palgrave Macmillan.

Jezic, Diane Peacock ([1988] 1994), Women Composers: The Lost Tradition Found. New York: The Feminist Press.

Kerman, Joseph (1985), Contemplating Music: Challenges to Musicology. Cambridge: Harvard University Press. 
Kielian-Gilbert, Marianne (2010), 'Music and the Difference in Becoming' in Brian Hulse and Nick Nesbitt (eds), Sounding the Virtual: Gilles Deleuze and the Theory and Philosophy of Music. Farnham, England and Burlington, VT: Ashgate, 199-225.

Koskoff, Ellen (2005), '(Left out in) left (the field): The effects of post-postmodern scholarship on feminist and gender studies in musicology and ethnomusicology, 19902000’, Women \& Music: A Journal of Gender and Culture, 9: 90-98.

Ladd, G. T. (1917), 'Why Women Cannot Compose Music', The Yale Review, 6/4: 789- 806. Larson, Libby (undated), 'Why are there so few Women Composers?', Libby Larson Website. (Accessed 30 October 2016), https://libbylarsen.com/index.php?contentID=234 Macarthur, Sally (1997), Feminist Aesthetics in Music: Politics and Practices in Australia. Ph.D. dissertation, University of Sydney.

Macarthur, Sally (2002), Feminist Aesthetics in Music. Westport, Connecticut and London: Greenwood Press.

Macarthur, Sally (2010), Towards a Twenty-First-Century Feminist Politics of Music. Farnham, England and Burlington, VT: Ashgate.

Macarthur, Sally (2013), 'Off key: women composers get a raw deal on play rates', The Conversation (Accessed 28 March 2015), https://theconversation.com/off-key-womencomposers-get-a-raw-deal-on-play-rates-17149

Macarthur, Sally (2014), ‘The Woman Composer, New Music and Neoliberalism’, Musicology Australia, 36/1: 36-52.

Macarthur, Sally, Hope, Cat and Bennett, Dawn (2016), ‘The Sound of Silence: Why aren’t Australia’s female composers being heard?’ The Conversation (Accessed 2 August 2016), https://theconversation.com/the-sound-of-silence-why-arent-australias-female-composersbeing-heard-59743, 
Macarthur, Sally, Lochhead, Judith, and Shaw, Jennifer (eds) (2016), Music's Immanent Future: The Deleuzian Turn in Music Studies. Abingdon, Oxon: Routledge.

Maddocks, Fiona (2011), 'Women Composers: Notes from the Musical Margins’, The Guardian [online] (Accessed 19 April 2017),

https://www.theguardian.com/music/2011/mar/13/london-oriana-choir-women-composers.

Mageau, Mary (1991). ‘Australian Women Composers’ Network: Aiming for Its Own Demise.’ 24 Hours, December: 50-52.

Mason, Bonita (2013), A Death in Custody Story: Critical Reflexivity in Journalism and Writing [Unpublished doctoral thesis]. Perth: Edith Cowan University.

Maus, Fred (2011), ‘Music, Gender and Sexuality’ in Martin Clayton, Trevor Herbert, and Richard Middleton (eds), 317-329, The Cultural Study of Music: A Critical Introduction. London and New York: Routledge.

Maus, Fred Everett (1993), 'Masculine discourse in music theory’, Perspectives of New Music, 13/2: 264-293.

McClary, Susan (1991), Feminine Endings: Music, Gender, and Sexuality. Minneapolis and Oxford: University of Minnesota Press.

McClary, Susan (1993), 'Reshaping a Discipline: Musicology and Feminism in the 1990s’, Feminist Studies 19/2: 399-423.

McClary, Susan (2000), Conventional Wisdom: The Content of Musical Form. Berkeley, Los Angeles and London: University of California Press.

McRobbie, Angela (2009) The Aftermath of Feminism: Gender, Culture and Social Change. London: Sage.

Mohr-Pietsch, Sara (2016), 'Women composers: genius is gender blind - and so should we be’, The Guardian, 6 March. (Accessed 25 September 2016), 
https://www.theguardian.com/music/musicblog/2015/mar/05/women-composers-genius$\underline{\text { radio-3-international-womens-day }}$

Morris, Christopher (2008-9), ‘Musicological Identities: Essays in Honor of Susan McClary’, Journal of the Society for Musicology in Ireland, 4: 55-65.

Nochlin, Linda (1973), 'Why Have There Been No Great Women Artists?’ in Hess, Thomas B., and Baker, Elizabeth C. (eds), Art and Sexual Politics. New York: Collier Books.

OECD Gender Portal [online] (Accessed 17 April 2017), https://www.oecd.org/gender/data/. Pendle, Karin (2005), Women in Music: A Research and Information Guide (New York and London: Routledge.

Pendle, Karin (ed.) (1991), Women \& Music: A History. Bloomington and Indianapolis: Indiana University Press.

Radic, Thérèse (1991), 'Where Are the Women Composers?’ 24 Hours, December: 43-46. Redhead, Lauren (2015), ‘New Music as a Patriarchal Category’ in Caroline Haworth and Lisa Colton (eds), 171-184, Gender, Age and Musical Creativity. Farnham, England and Burlington, VT: Ashgate.

Rieger, Eva (1981/1988), Frau, Musik, und Männerherrschaft. Frankfurt, Germany: Ullstein; Kassel, Germany: Furore-Verlag.

Rieger, Eva (1992), “'II Recycle Sounds”: Do Women Compose Differently?’, Journal of the International League of Women Composers: 22-25.

Rogers, Victoria V., Baldock, Cora, and Mulligan, Denise (1993), What Difference Does It Make? A Pilot Study of Women in the Performing and Visual Arts in Western Australia. Sydney: Australia Council.

Rubin-Rabson, J. (1973), ‘Why Haven’t Women Become Great Composers?’, High Fidelity/Musical America, XXIII/2: 47-50. 
Rusak, Helen Kathryn (2005), Simply Divine: Feminist aesthetics in three music-theatre works of Elena Kats-Chernin. PhD Thesis, University of Adelaide.

Sadie, Julie Anne, and Samuel, Rhian (eds) (1994), The New Grove Dictionary of Women Composers. London: Macmillan Press.

Seashore, C. E. (c. 1947), 'Why No Great Women Composers?’ in In Search of Beauty in Music: A Scientific Approach to Musical Aesthetics. New York: Ronald Press, 363-67. Smith, Chris, and Mckinlay, Alan (2009) 'Creative labour: Content, contract and control' in McKinlay, Alan, and Smith, Chris (eds), Creative labour: Working in the creative industries. New York: Palgrave, 29-50.

Cox, Renée (1991), 'Recovering Jouissance: An Introduction to Feminist Musical Aesthetics’ in Pendle, Karin (ed.), Women and Music: A History. Bloomington and Indiannapolis: Indiana University Press, 331-340.

Shapiro, Alex (2016), 'Roundtable: Let’s Make a List' (Accessed 30 October 2016), New Music Box, http://www.newmusicbox.org/articles/lets-make-a-list/

Soli, Ruth A. (ed.) (1993), Musicology and Difference: Gender and Sexuality in Music Scholarship. Berkeley, Los Angeles, and London: University of California Press.

Solie, Ruth A. (1991), 'What Do Feminists Want? A Reply to Pieter van den Toorn', The Journal of Musicology 9/4: 399-410.

Thompson, Damian (2015), ‘There’s a good reason why there are no great female composers', The Spectator, 16 September. (Accessed 25 September 2016), https://songofthelark.files.wordpress.com/2015/09/spectator-1024x844.png. .

Wood, Elizabeth (1980), 'Review Essay: Women in Music’, Signs, 6/2: 283-297. Wright, Katy (2016), 'Basca research reveals lack of gender and BAME diversity in composition', Classical Music, Issue 1023, August: 8-8. 


\section{Author Biographies}

Sally Macarthur (PhD, University of Sydney) is Associate Professor of Musicology and Director of Academic Program, Music, at Western Sydney University. She is co-editor (with Judy Lochhead and Jennifer Shaw) of Music's Immanent Future: The Deleuzian Turn in Music Studies (Routledge, 2016), and has written two monographs, Towards a TwentiethFirst-Century Feminist Politics of Music (Ashgate, 2010) and Feminist Aesthetics in Music (Greenwood Press, 2002).

Email: s.macarthur@westernsydney.edu.au

Dawn Bennett is John Curtin Distinguished Professor of Higher Education with Curtin University and Director of the Creative Workforce Initiative. Her research is focused on developing employability within higher education learning and teaching, including identity development and graduate work.

Email: d.bennett@curtin.edu.au

Talisha Goh (Western Australian Academy of Performing Arts, Edith Cowan University), is a musicology $\mathrm{PhD}$ candidate with a dissertation focus on contemporary Australian women composers. Research interests include Australian music history, gender studies and multidisciplinary studies.

Email: talishag@our.ecu.edu.au 
Sophie Hennekam (ESC La Rochelle School of Business, France) is an Associate Professor interested in identity transitions, diversity management and the creative workforce. She has published in journals such as Human Relations and Human Resource Management Journal.

Email: hennekamso@esc-larochelle.fr

Cat Hope is Professor and Head of Music at the Sir Zelman Cowen School of Music, Monash University, and a composer, sound artist, musician and artistic director. She is the co- author of Digital Arts: An introduction to New Media (Bloomsbury, 2014) and Director of the Decibel New Music Ensemble. Her research includes digital music archives, graphic notations and very low frequency sound.

Email: cat.hope@monash.edu 